Keywords:

Spatial models

Descriptive statistics

Soil conservation

Sustainability

Histórico:

Recebido 31/03/2016

Aceito 22/09/2016

Palavras chave:

Modelos espaciais

Estatística descritiva

Conservação do solo

Sustentabilidade

${ }^{+}$Correspondência: mgervasiopereira0I@gmail.com
Camila Santos da Silva', Marcos Gervasio Pereira' ${ }^{\prime+}$, Rafael Coll Delgado', Eduardo Vinícius da Silva'

\section{SPATIALIZATION OF SOIL CHEMICAL AND PHYSICAL ATTRIBUTES IN AN AGROFORESTRY SYSTEM, SEROPÉDICA, BRAZIL}

ABSTRACT: The purpose of this study was to spatialize the chemical and physical attributes of the soil in an agroforestry system in Seropédica, Rio de Janeiro, Brazil. Thirtyone soil samples were collected from 0-10 cm, 10-20 cm, and 20-40 cm depths, and each sampling point was georeferenced. The $\mathrm{pH}$ (in $\left.\mathrm{H}_{2} \mathrm{O}\right)$, potential acidity $(\mathrm{H}+\mathrm{Al})$, calcium $\left(\mathrm{Ca}^{+2}\right)$, magnesium $\left(\mathrm{Mg}^{+2}\right)$, aluminum $\left(\mathrm{Al}^{+3}\right)$, sodium $\left(\mathrm{Na}^{+}\right)$, potassium $\left(\mathrm{K}^{+}\right)$, phosphorus $(\mathrm{P})$, organic carbon $(\mathrm{C})$, cation exchange capacity of the soil ( $\mathrm{T}$ value), base saturation $(\mathrm{V}$ value), total clay, total sand, silt, and density of fine roots were measured. The software ArcGIS 10.2 was used to perform the semivariogram analysis and the fitting of the models, and spatial interpolation was performed using a first-order trend ordinary kriging process with spherical, exponential, and Gaussian spatial models. Based on the results, only the exponential and Gaussian models were fitted to the variables, except for the $\mathrm{Mg}^{2+}$ and $\mathrm{V}$ value variables, which presented no spatial dependence, thus showing a pure nugget effect (PNE). Distribution maps were generated for the variables (except for those exhibiting $\mathrm{PNE}$ ), which showed correlation between the variables $\mathrm{pH}$ and $\mathrm{Al}^{3+}$, organic carbon and cations, phosphorus and total clay, and silt and sand. Overall, geostatistics could be applied to spatialize the chemical and physical attributes of the soil in the agroforestry system, except in the case of $\mathrm{Mg}^{2+}$ and the $\mathrm{V}$ value.

\section{ESPACIALIZAÇÃO DOS ATRIBUTOS QUÍMICOS E FÍSICOS DO SOLO EM UM SISTEMA AGROFLORESTAL, SEROPÉDICA, BRASIL}

RESUMO: Neste trabalho, objetivou-se espacializar os atributos químicos e físicos do solo em um sistema agroflorestal no município de Seropédica, Rio de Janeiro. Foram coletadas 31 amostras de terra, nas profundidades de $0-10 \mathrm{~cm}, 10-20 \mathrm{~cm}$ e $20-40 \mathrm{~cm}$, sendo cada ponto de coleta georreferenciado. Foram determinados $\mathrm{pH}\left(\mathrm{em} \mathrm{H}_{2} \mathrm{O}\right)$, acidez potencial $(\mathrm{H}+\mathrm{Al})$, cálcio $\left(\mathrm{Ca}^{2+}\right)$, magnésio $\left(\mathrm{Mg}^{2+}\right)$, alumínio $\left(\mathrm{Al}^{3+}\right)$, sódio $\left(\mathrm{Na}^{+}\right)$, potássio $\left(\mathrm{K}^{+}\right)$, fósforo $(\mathrm{P})$, carbono orgânico $(\mathrm{C})$, capacidade de troca catiônica do solo (Valor $\left.\mathrm{T}\right)$, saturação por bases (Valor $\mathrm{V}$ ), argila total, areia total, silte e densidade de raízes finas. O software ArcGIS 10.2 foi utilizado para fazer a análise semivariográfica e o ajuste dos modelos, e posteriormente, foi empregado a interpolação espacial através da Krigagem Ordinária de primeira ordem de três modelos espaciais, esférico, exponencial e gaussiano. De acordo com os resultados, apenas os modelos exponencial e gaussiano foram ajustados para as variáveis, exceto para as variáveis $\mathrm{Mg}^{2+} \mathrm{e}$ Valor $\mathrm{V}$, pois não apresentaram dependência espacial, assim expressando efeito pepita puro (EPP). Foram gerados os mapas de distribuição para as variáveis (exceto para aquelas que exibiram EPP), onde ocorreu uma correlação entre as variáveis $\mathrm{pH}$ e $\mathrm{Al}^{3+}$, carbono orgânico e cátions, fósforo e argila total, e silte e areia. A geoestatística pode ser aplicada para espacializar os atributos químicos e físicos do solo no sistema agroflorestal, exceto no caso do $\mathrm{Mg}^{2+}$ e Valor V. 


\section{INTRODUCTION}

Agroforestry systems (AFSs) are a sustainable form of production and are recommended as an alternative system for family farms (LIMA et al., 20I I). They are also an effective way to promote soil conservation, as they restore degraded areas, protect soils and water basins, increase carbon sequestration, improve the climate, and increase biodiversity (MÉIER et al., 20I I).

Owing to the various vegetation strata that can form from the species in the AFS, there may be management difficulties due to the complexity of providing light, water, and nutrients for all species (DONATO; LIMA, 20/3). Thus, it is essential to determine how management practices may interfere with nutrient availability. Nutrient concentrations can be quantified in order to simulate the results of these factors in these production systems (LIMA et al., 20I I).

In order to increase productivity by using different fertilizers, and soil and crop management practices, a careful analysis of the variability of soil attributes is needed so that management alternatives can be recommended to reduce the effects of the variability on crop production (DALCHIAVON et al., 20I2).

Geostatistical studies, with the objective of understanding spatial variability of soil attributes, have recently been gaining prominence and importance in Brazil (BOTTEGA et al., 2013; ZONTA et al., 20l4). This tool has been widely used in soil science and other sciences to characterize and analyze the spatial variation of characteristics (BOTTEGA et al., 2013; GOIS et al., 2015), and enables the production of maps through kriging (DALCHIAVON et al., 20I2).

Currently, there are no geostatistical studies on the spatialization of soil attributes in the agroforestry system of the Integrated Agroecological Production System, and this knowledge could help optimize the system's labor and management requirements. Thus, the purpose of this study was to spatialize the chemical and physical attributes of the soil in an agroforestry system in Seropédica, Rio de Janeiro, Brazil.

\section{MATERIAL AND METHODS}

\section{Area of Study}

The study was performed in an AFS of approximately $3,397 \mathrm{~m}^{2}$, located in the Integrated Agroecological Production System (SIPA), also known as the $\mathrm{Km} 47$ Agroecological Farm, on the Embrapa Agrobiology grounds in Seropédica, Rio de Janeiro, Brazil (Figure I).

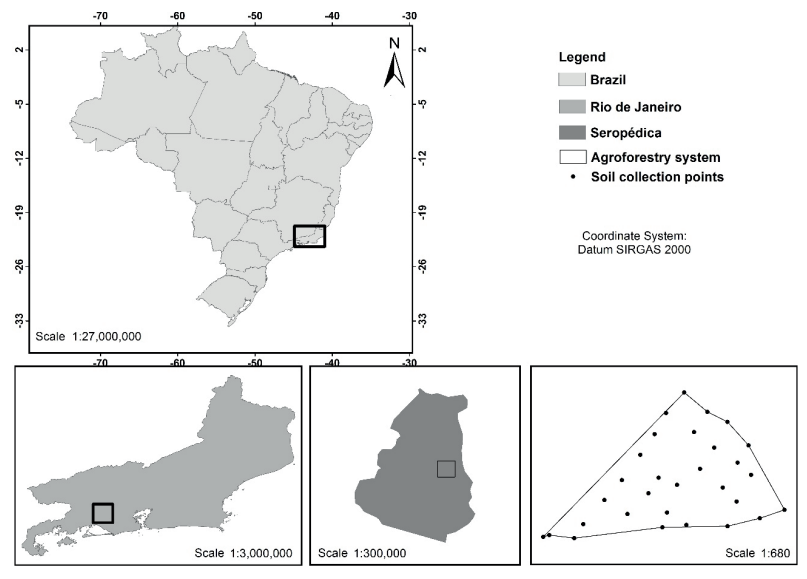

FIGURE I Location of the agroforestry system, in the Integrated Agroecological Production System in Seropédica, Rio de Janeiro, Brazil.

The climate of the region is Aw (Köppen classification), with rains concentrated between November and March, an annual average precipitation of $\mathrm{I}, 213 \mathrm{~mm}$, and an average annual temperature of $23.9^{\circ} \mathrm{C}$ (CARVALHO et al., 20II). The maximum and minimum altitude of the AFS is $41.0 \mathrm{~m}$ and $26.3 \mathrm{~m}$, respectively. The land relief is predominantly soft-wavy ( $<5 \%$ declivity), and the soil is classified as Haplic Planosol (SANTOS et al., 2013).

The area had monocultures of Musa sapientum L. and Carica papaya L. before the AFS is implemented, which were fertilized only with cattle manure.

The agroforestry system implementation started in 2000 with a multilayered arrangement. Species such as açaí (Euterpe oleracea Mart.), cupuaçu (Theobroma grandiflorum), grumixama (Eugenia brasiliensis Lam.), citrus (Citrus sp.) and guapuruvu (Schizolobium parahyba (Jacq.) Walp.) were planted along with cabbage and forage peanut crops, the latter as green manure. Some species that previously existed on the site were used, such as the flamboyant (Delonin regia Bojer ex Hook.), due to its beauty in the landscape.

New species, such as gliricidia (Gliricidia sepium (Jacq.) Walp.), jaca (Artocarpus beterophyllus Lam.), carrapeta (Guarea Guidonia (L.) Sleumer), tucandeiro (Citharexylum myrianthum Cham.) and some species of the Arecaceae family were planted from 2002 to 2008.

The most intense management was carried out in the first two years, with the aforementioned plantings; pruning; mowing; manuring; harvesting and weeding. After the first eight years, there are no reports of management practices used in the area.

\section{Sampling and Georeferencing}

The area was divided into $10 \times 10 \mathrm{~m}\left(100 \mathrm{~m}^{2}\right)$ plots in which 3 I sampling units were installed. Soil samples 
were collected from the center of each plot at the depths of $0-10 \mathrm{~cm}, 10-20 \mathrm{~cm}$, and $20-40 \mathrm{~cm}$ using of a probe that was $4.5 \mathrm{~cm}$ in diameter and $130 \mathrm{~cm}$ in length.

The soil samples were taken to the laboratory, dried in the shade, and then crushed and screened through a 2-mm sieve, thus obtaining air-dried fine earth (ADFE) that was used to perform the analyses.

After the soil collections, each point was georeferenced with a Promark 2 geodetic GPS device.

\section{Analyses of the Chemical and Physical Attributes}

The ADFE samples were used to evaluate the chemical and physical attributes of the soil, namely: $\mathrm{pH}$ (in $\left.\mathrm{H}_{2} \mathrm{O}\right)$, potential acidity $(\mathrm{H}+\mathrm{Al})$, calcium $\left(\mathrm{Ca}^{+2}\right)$, magnesium $\left(\mathrm{Mg}^{+2}\right)$, aluminum $\left(\mathrm{Al}^{+3}\right)$, sodium $\left(\mathrm{Na}^{+}\right)$, potassium $\left(\mathrm{K}^{+}\right)$, phosphorus $(\mathrm{P})$, organic carbon $(\mathrm{C})$, cation exchange capacity of the soil ( $T$ value), and base saturation for the chemical attributes ( $V$ value). For the physical attributes, a particle size analysis was performed, and the values of total clay $\left(\mathrm{g} \cdot \mathrm{kg}^{-1}\right)$, total sand $\left(\mathrm{g} \cdot \mathrm{kg}^{-1}\right)$, and silt $\left(\mathrm{g} \cdot \mathrm{kg}^{-1}\right)$ were quantified. All laboratory procedures followed the protocols established by Embrapa (1997).

\section{Determination of Fine Root Density}

The ADFE was obtained with a digital caliper ruler and the roots with a maximum diameter of $2 \mathrm{~mm}$ were separated, and weighed and placed in an oven at $65^{\circ} \mathrm{C}$ for three days. After the fine roots were dry, they were again weighed to obtain the dry biomass. The density of the fine roots $\left(\mathrm{g} \cdot \mathrm{cm}^{-3}\right)$ was calculated for each sample, based on the ratio between the dry weight of the fine roots and the volume of the probe. The sum of the roots with density of up to $40 \mathrm{~cm}$ depth were considered for the analysis.

\section{Geostatistical Analysis}

The data obtained in the analyses of the chemical and physical attributes of the soil, and the density of the fine roots, were entered into Microsoft Excel 2013 spreadsheets, and the weighted averages were calculated for each plot based on the thickness of the soil layer collected. Next, geographic coordinates were associated with each sample, enabling data spatialization.

The software program ArcGIS 10.2 was used for the spatialization and preparation of the variable distribution maps, and a first-order trend ordinary kriging process was used as the spatial interpolation method.

Three transitive theoretical models (exponential, spherical, and Gaussian) were fitted to the variables, in order to verify which model best represented the distribution of the variables studied, based on the equations and the three physical models presented by Gois et al. (20I5).
Semivariogram model fitting was conducted for the analysis of the models, using the degree of spatial dependence (DSD\%) for choosing the best model.

The DSD used in this study was based on the method proposed by Cambardella et al. (1994), where: DSD values $\leq 25 \%$ suggest data with strong spatial dependence; between $25 \%$ and $75 \%$, moderate spatial dependence; $\geq 75 \%$, weak spatial dependence; and for a DSD equal to $100 \%$, the variable is spatially independent - the semivariogram shows a pure nugget effect (PNE). The DSD was calculated using equation I, where DSD is the degree of spatial dependence, $C_{0}$ is the nugget effect, and $\mathrm{C}_{0}+\mathrm{C}$ is the baseline.

$\mathrm{DSD}=\frac{\mathrm{C}_{0}}{\mathrm{C}_{0}+\mathrm{C}} \times 100$

\section{Statistical Analysis}

Statistical analysis was applied to the AFS in order to assess the performance of the transitive theoretical models based on the following parameters presented by Vieira (20II) and Gois et al. (20I5): root-mean-square error (RMSE), index of agreement (d), standard error of the estimate (SEE), Pearson correlation coefficient ( $r$ ), and coefficient of determination $\left(r^{2}\right)$, as shown in [2], [3], [4], [5] and in which $O_{i}$ is equal to the observed values, $P_{i}$ is equal to the predicted values, $\bar{O}$ is the average of the observed values, $\bar{P}$ is the average of the predicted values, and $\mathrm{n}$ is equal to the number of data analyzed.

$$
\begin{gathered}
\text { RMSE }=\sqrt{\frac{\sum_{\mathrm{i}=1}^{\mathrm{n}}\left(\mathrm{O}_{\mathrm{i}}-\mathrm{P}_{\mathrm{i}}\right)^{2}}{\mathrm{n}}} \\
\mathrm{d}=1-\frac{\sum_{\mathrm{i}=1}^{\mathrm{n}}\left(\mathrm{P}_{\mathrm{i}}-\mathrm{O}_{\mathrm{i}}\right)^{2}}{\sum\left(\left|\mathrm{P}_{\mathrm{i}}-\overline{\mathrm{O}}\right|+\left|\mathrm{O}_{\mathrm{i}}-\overline{\mathrm{O}}\right|\right)^{2}}
\end{gathered}
$$

$\mathrm{SEE}=\sqrt{\frac{\sum_{\mathrm{i}=1}^{\mathrm{n}}\left(\mathrm{O}_{\mathrm{i}}-\mathrm{P}_{\mathrm{i}}\right)^{2}}{\mathrm{n}-2}}$

$$
r=\frac{\sum_{i=1}^{n}\left(P_{i}-\bar{P}\right) \times\left(O_{i}-\bar{O}\right)}{\sqrt{\sum_{i=1}^{n}\left(P_{i}-\bar{P}\right)^{2} \times \sum_{i=1}^{n}\left(O_{i}-\bar{O}\right)^{2}}}
$$

$$
r^{2}=\left(\frac{\sum_{i=1}^{n}\left(P_{i}-\bar{P}\right) \times\left(O_{i}-\bar{O}\right)}{\sqrt{\sum_{i=1}^{n}\left(P_{i}-\bar{P}\right)^{2} \times \sum_{i=1}^{n}\left(O_{i}-\bar{O}\right)^{2}}}\right)^{2}
$$

\section{RESULTS AND DISCUSSION}

\section{Semivariogram}

The exponential and Gaussian models were fitted to the variables (Table I), except for $\mathrm{Mg}^{2+}$ and the $V$ value, which both had DSD greater than 100\%, indicating that these variables are spatially independent. 
In other words, their semivariograms exhibited a pure nugget effect (PNE). The variables $\mathrm{Na}^{+}, \mathrm{C}$, total clay, silt, and density of fine roots showed strong DSD, while the variables $\mathrm{pH}, \mathrm{H}+\mathrm{Al}, \mathrm{Ca}^{2+}, \mathrm{Al}^{3+}, \mathrm{K}^{+}, \mathrm{P}$, total sand, and $\mathrm{T}$ value showed moderate DSD.

According to Cambardella et al. (1994), the PNE indicates that the variability was not explained or the variation was not detected, which may occur due to measurement or sampling errors, or undetected microvariation. The sample spacing was probably another factor that influenced this result, due to the distances between the sampling points, once this distance may have been overestimated, contributing to the nonexpression of spatial dependence.

Using precision agriculture to establish management strategies in Boa Vista das Missões in Rio Grande do Sul, Cherubin et al. (20I I) found results that differed from those observed in this study. The authors noted that spatial dependence was moderate for the $\mathrm{V}$ value (\%) and strong for $\mathrm{Mg}^{2+}$, and the exponential model was fitted to both attributes. The saturation by aluminum (m\%) variable and $\mathrm{Al}^{3+}$ showed a PNE.

TABLE I Parameters of semivariance models for soil variables, in the Integrated Agroecological Production System in Seropédica, Rio de Janeiro, Brazil.

\begin{tabular}{|c|c|c|c|c|c|}
\hline Variable & Model & $\mathrm{CO}^{(1)}$ & $\mathrm{CO}+\mathrm{C}^{(2)}$ & $\begin{array}{c}\mathrm{DSD}^{(3)} \\
(\%) \\
\end{array}$ & Class \\
\hline $\mathrm{pH}$ & $\operatorname{Exp}^{(4)}$ & 0.21 & 0.37 & 56.26 & Moderate \\
\hline $\begin{array}{c}\mathrm{H}+\mathrm{Al} \\
\left(\mathrm{cmolc} \cdot \mathrm{dm}^{-3}\right)\end{array}$ & Exp & 0.60 & 1.46 & 41.46 & Moderate \\
\hline $\begin{array}{c}\mathrm{Ca}^{2+} \\
\left(\mathrm{cmolc} \cdot \mathrm{dm}^{-3}\right)\end{array}$ & Exp & 1.08 & 2.54 & 42.72 & Moderate \\
\hline $\begin{array}{c}\mathrm{Mg}^{2+} \\
\left(\mathrm{cmolc} \cdot \mathrm{dm}^{-3}\right)\end{array}$ & $\mathrm{PNE}^{(5)}$ & 0.37 & 0.37 & 100.00 & PNE \\
\hline $\begin{array}{c}\mathrm{Al}^{3+} \\
\left(\mathrm{cmolc} \cdot \mathrm{dm}^{-3}\right)\end{array}$ & Exp & 0.02 & 0.03 & 58.80 & Moderate \\
\hline $\begin{array}{c}\mathrm{Na}^{+} \\
\left(\mathrm{cmolc} \cdot \mathrm{dm}^{-3}\right)\end{array}$ & $\mathrm{Gau}^{(6)}$ & 0.00 & 0.01 & 6.27 & Strong \\
\hline $\begin{array}{c}\mathrm{K}^{+} \\
\left(\mathrm{cmolc} \cdot \mathrm{dm}^{-3}\right)\end{array}$ & Gau & 0.00 & 0.00 & 52.49 & Moderate \\
\hline $\begin{array}{c}\mathrm{P} \\
\left(\mathrm{mg} \cdot \mathrm{dm}^{-3}\right)\end{array}$ & Exp & 504.18 & 1752.88 & 28.76 & Moderate \\
\hline$C\left(\mathrm{~g} \cdot \mathrm{kg}^{-1}\right)$ & Gau & 1.14 & 409.17 & 19.83 & Strong \\
\hline $\begin{array}{c}\text { Total clay } \\
\left(\mathrm{g} \cdot \mathrm{kg}^{-1}\right)\end{array}$ & Exp & 858.92 & 4708.22 & 18.24 & Strong \\
\hline $\begin{array}{l}\text { Total sand } \\
\left(\mathrm{g} \cdot \mathrm{kg}^{-1}\right)\end{array}$ & $\operatorname{Exp}$ & 4852.60 & 13004.30 & 37.32 & Moderate \\
\hline $\begin{array}{c}\text { Silt } \\
\left(g \cdot \mathrm{kg}^{-1}\right)\end{array}$ & Gau & 3679.60 & 16978.60 & 21.67 & Strong \\
\hline $\begin{array}{l}\text { Pensity of fine roots } \\
\qquad\left(\mathrm{g} \cdot \mathrm{dm}^{-3}\right)\end{array}$ & Exp & 0.00 & 0.00 & 25.30 & Strong \\
\hline $\begin{array}{c}\text { T value } \\
\left(\mathrm{cmolc} \cdot \mathrm{dm}^{-3}\right)\end{array}$ & Gau & 1.69 & 4.59 & 36.79 & Moderate \\
\hline $\begin{array}{c}\text { V value } \\
(\%)\end{array}$ & PNE & 125.65 & 125.65 & 100.00 & PNE \\
\hline
\end{tabular}

(1) nugget effect; ${ }^{(2)}$ baseline; (3) degree of spatial dependence; ${ }^{(4)}$ exponential; (5) pure nugget effect; ${ }^{(6)}$ Gaussian.
In Nossa Senhora do Livramento (Mato Grosso, Brazil), geostatistics were used to characterize the spatial variability of the chemical attributes of the soil in a population of Tectona grandis over two evaluation periods (PELISSARI et al. 20I4). Their results differed from the results of this current study, specifically: the Gaussian and exponential models were fitted to the variable $\mathrm{pH}$; the spherical and Gaussian models were fitted to $\mathrm{Ca}^{+}, \mathrm{Mg}^{2+}$, and $\mathrm{Al}^{3+}$; and the spherical model for the second and ninth year of cultivation was fitted to $\mathrm{K}^{+}$.

In Angatuba, São Paulo, Vieira et al. (20 I I) studied the spatial variability of the physical and chemical attributes of two Latosols in a no-tillage system and their relationship with the stability of the aggregates. Similar to this current study, they noted that the fitted exponential model was the model that best fit the clay physical attribute, with a degree of spatial dependence of $29.80 \%$. On the other hand, the spherical model was fitted to the total sand variable for Angatuba and Campos Novos Paulista.

Using geostatistical methods to study the variability of the particle size fractions of soil in Fortaleza, Cajazeira and Assis Júnior (20I I) noted that the spherical model was the model that best fitted to the analysis of the sand, silt, and clay attributes at the depths of $0-20 \mathrm{~cm}$ and $20-40 \mathrm{~cm}$.

\section{Statistical Analysis}

According to the statistical analysis of the soil attributes (Table 2), the index of agreement (d) was lower for $\mathrm{Mg}^{2+}(0.33)$ and $\mathrm{V}$ value (0.44), and higher for the $\mathrm{T}$ value $(0.78)$ and $\mathrm{Na}^{+}(0.74)$, than for the other variables.

The Pearson correlation coefficient $(r)$ was lower for the $V$ value $(-0.18)$ and $\mathrm{Mg}^{2+}(-0.2 \mathrm{I})$ than for the other variables, and indicated a negative correlation between the real and predicted values. This parameter (r) was closer to I for $\mathrm{Na}^{+}(0.85)$ and total clay (0.60) than for the other variables, indicating that there was a strong positive correlation between the observed and estimated values for these variables.

Similarly, Vieira et al. (20II) studied the spatial variability of the physical and chemical attributes of two Latosols (São Paulo) and noted that the $r$ parameter was low for $\mathrm{Mg}^{2+}$ - $(0.1583$ and 0.3550 for the cities of Angatuba and Campos Novos Paulista, respectively) and that the values for the textural attributes of the soil (total clay and sand) were high.

The coefficient of determination $\left(r^{2}\right)$ ranged between 0.03 and 0.72 , where the lowest value corresponded to the $\mathrm{V}$ value and the highest to $\mathrm{Na}^{+}$. This result indicates that the closer this parameter is to one, the higher the correlation between the found and estimated data. These results differed from those 
TABLE 2 Statistical analysis of the soil chemical and physical attributes in the agroforestry system of the Integrated Agroecological Production System.

\begin{tabular}{|c|c|c|c|c|c|}
\hline Variable & $d^{(1)}$ & $r^{(2)}$ & $r^{2(3)}$ & $\mathrm{SEE}^{(4)}$ & $\mathrm{RMSE}^{(5)}$ \\
\hline $\mathrm{pH}$ & 0.61 & 0.36 & 0.13 & 0.22 & 0.93 \\
\hline $\mathrm{H}+\mathrm{Al}$ & 0.63 & $0.4 I$ & 0.17 & 0.53 & 0.98 \\
\hline$\left(\mathrm{cmolc} \cdot \mathrm{dm}^{-3}\right)$ & & & & & \\
\hline $\mathrm{Ca}^{2+}$ & 0.61 & 0.21 & 0.05 & 0.63 & 1.07 \\
\hline $\begin{array}{c}\left(\mathrm{cmolc} \cdot \mathrm{dm}^{-3}\right) \\
\mathrm{Mg}^{2+}\end{array}$ & 0.33 & -0.21 & 0.04 & 0.12 & 1.01 \\
\hline $\begin{array}{c}\left(\mathrm{cmolc} \cdot \mathrm{dm}^{-3}\right) \\
\mathrm{Al}^{3^{+}}\end{array}$ & 0.64 & 0.33 & 0.11 & 0.07 & 0.95 \\
\hline $\begin{array}{c}\left(\mathrm{cmolc} \cdot \mathrm{dm}^{-3}\right) \\
\mathrm{Na}^{+}\end{array}$ & 0.74 & 0.85 & 0.72 & 0.03 & 1.16 \\
\hline $\begin{array}{c}\left(\mathrm{cmolc}_{\mathrm{dm}} \mathrm{dm}^{-3}\right) \\
\mathrm{K}^{+} \\
\left(\mathrm{cmolc}^{\left.-\mathrm{dm}^{-3}\right)}\right.\end{array}$ & 0.68 & 0.46 & 0.21 & 0.03 & 0.98 \\
\hline $\begin{array}{c}P \\
\left(m \sigma \cdot \mathrm{dm}^{-3}\right)\end{array}$ & 0.64 & 0.31 & 0.10 & 20.20 & 1.03 \\
\hline $\begin{array}{c}\left(\mathrm{mg} \cdot \mathrm{dm}^{-3}\right) \\
\mathrm{C} \\
\left(\mathrm{g} \cdot \mathrm{kg}^{-1}\right)\end{array}$ & 0.59 & 0.31 & 0.10 & 6.18 & 1.22 \\
\hline $\begin{array}{l}\text { Total clay } \\
\left(\mathrm{g}^{\mathrm{k}} \mathrm{kg}^{-1}\right)\end{array}$ & 0.65 & 0.60 & 0.36 & 26.62 & 0.94 \\
\hline $\begin{array}{l}\text { Total sand } \\
\left(\mathrm{g} \cdot \mathrm{kg}^{-1}\right)\end{array}$ & 0.59 & 0.43 & 0.18 & 46.92 & 1.00 \\
\hline $\begin{array}{l}\text { Silt } \\
\left(g \cdot \mathrm{kg}^{-1}\right)\end{array}$ & 0.58 & 0.41 & 0.16 & 42.08 & 1.15 \\
\hline $\begin{array}{l}\text { Density of fine roots } \\
\qquad\left(\mathrm{g} \cdot \mathrm{dm}^{-3}\right)\end{array}$ & 0.64 & 0.32 & 0.10 & 0.00 & 1.07 \\
\hline T value & 0.78 & 0.54 & 0.29 & 1.10 & 1.04 \\
\hline $\begin{array}{c}\left(\mathrm{cmolc} \cdot \mathrm{dm}^{-3}\right) \\
\vee \text { value } \\
(\%)\end{array}$ & 0.44 & -0.18 & 0.03 & 2.21 & 1.00 \\
\hline
\end{tabular}

(1) index of agreement; (2) Pearson correlation coefficient; ${ }^{(3)}$ coefficient of determination; ${ }^{(4)}$ standard error of the estimate; ${ }^{(5)}$ root-mean-square error.

obtained by Zucoloto et al. (20I I), who used classical statistics and geostatistics to evaluate the correlation and spatial variability of soil chemical attributes, and the production of dwarf lady finger bananas in Espírito Santo. They found a higher value, close to 0.92 , for the coefficient of determination for the $V$ value.

The SEE exhibited high variation among the variables studied, where the lowest error of $0 \mathrm{~g} \cdot \mathrm{cm}^{-3}$ was observed for the density of fine roots; no error occurred between the observed and estimated data. On the other hand, the highest SEE, $46.92 \mathrm{~g} \cdot \mathrm{kg}^{-1}$, was noted for total sand, indicating a greater error between the real and predicted data.

All variables showed low values of Root Mean Square Error (RMSE), demonstrating the quality of the fitting of the models, as described by Martins et al. (20/4). In their study in Piracicaba, they noted the potential of using hyperspectral data, originating from samples from the field and oven-dried fine earth conditions, to determine certain chemical and physical attributes of soil that had been subjected to different applications of vinasse doses.

\section{Spatial distribution}

Based on the statistical parameters, spatial distribution maps of the chemical and physical attributes of the soil were generated (Figures 2 and 3), except for PNE variables, $\mathrm{Mg}^{2+}$ and $\mathrm{V}$ value.

An analysis of Figures 2A and 2D revealed that there was a negative correlation between $\mathrm{pH}$ and $\mathrm{Al}^{3+}$, with the areas with the lowest $\mathrm{pH}$ having the highest concentrations of aluminum. According to Sousa et al. (2007), the $\mathrm{pH}$ decreases with the increase of $\mathrm{Al}^{3+}$ ions in the soil solution, affecting the availability of some nutrients to plants and the activity of microorganisms.

In the areas with the highest concentrations of organic carbon (Figure $2 \mathrm{H}$ ) the highest values of $\mathrm{Ca}^{2+}$, $\mathrm{Na}^{+}$, and $\mathrm{K}^{+}$(Figures $2 \mathrm{C}, 2 \mathrm{E}$, and $2 \mathrm{~F}$ ) were also found and, consequently, a higher T value (Figure 3E). According to a study performed by Artur et al. (2014) in Chapada do Apodi, Ceará, Brazil, this correlation between carbon content and concentration of positive ions is related to the high capacity of cation retention by the organic matter due to the increase of negative charges, which contribute to the nutrient retention.

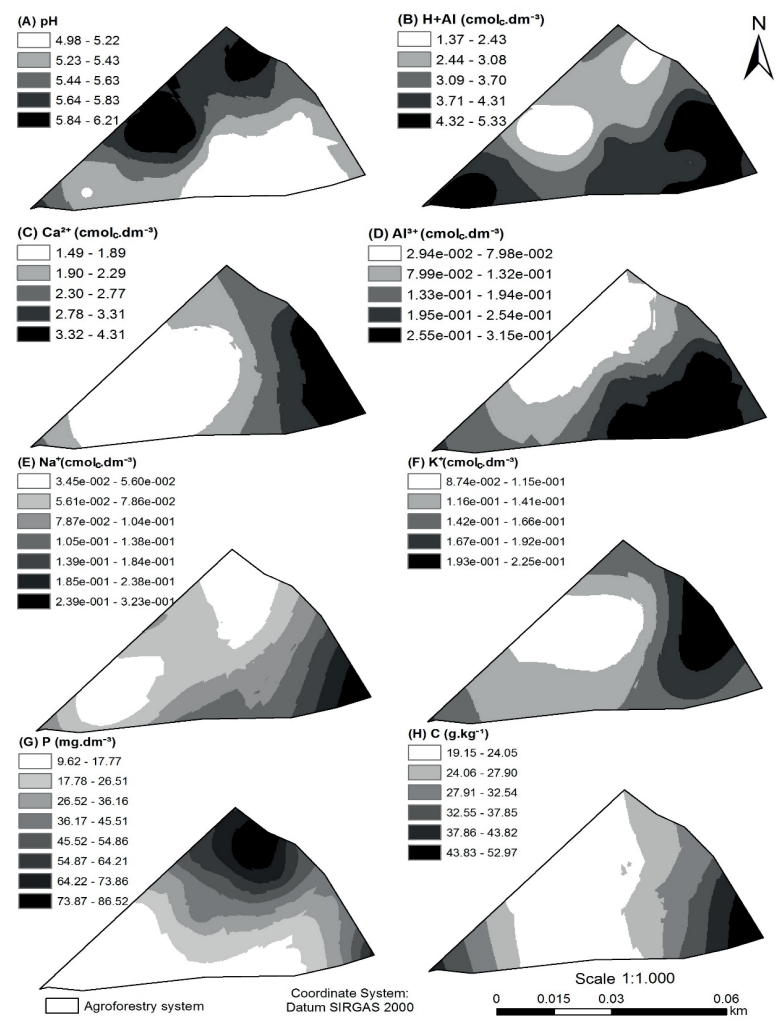

FIGURE 2 Spatial distribution maps of $\mathrm{pH}(\mathrm{A}), \mathrm{H}+\mathrm{Al}(\mathrm{B})$, $\mathrm{Ca}^{2+}(\mathrm{C}), \mathrm{Al}^{3+}(\mathrm{D}), \mathrm{Na}^{+}(\mathrm{E}), \mathrm{K}^{+}(\mathrm{F}), \mathrm{P}(\mathrm{G})$, and $\mathrm{C}$ $(\mathrm{H})$ in the agroforestry system of the Integrated Agroecological Production System. 
The results of the present work, in which the regions with higher carbon contents were the ones with the AFS of lower altitudes, may be related to the type of soil (Planosol), since it presents sandy texture in the surface, abruptly changing to a clayey texture in the subsurface, where it is compact and almost impermeable (SOUSA et al., 20I3), thus compromising the decomposition of soil organic matter.

The previous results are corroborated by those obtained by Ebeling et al. (20II), Briedis et al. (20I2), and Matias et al. (20I5), who found a positive correlation between organic carbon (or organic material) and the cation exchange capacity (CEC), where carbon is the main contributor to the increase in the CEC and the increase in nutrient adsorption.

An analysis of Figure $2 \mathrm{G}$ showed that the regions with higher concentrations of $P$ are those that showed lower quantities of total clay (Figure 3A) and the highest quantities of total sand (Figure 3B), corroborating the results of Corrêa et al. (20I I), Tokura et al. (20I I), and Bezerra et al. (2013). According to Novais et al. (2007), this result is due to the adsorption of phosphorus by oxyhydroxides of $\mathrm{Fe}$ and $\mathrm{Al}$, which are present in greater

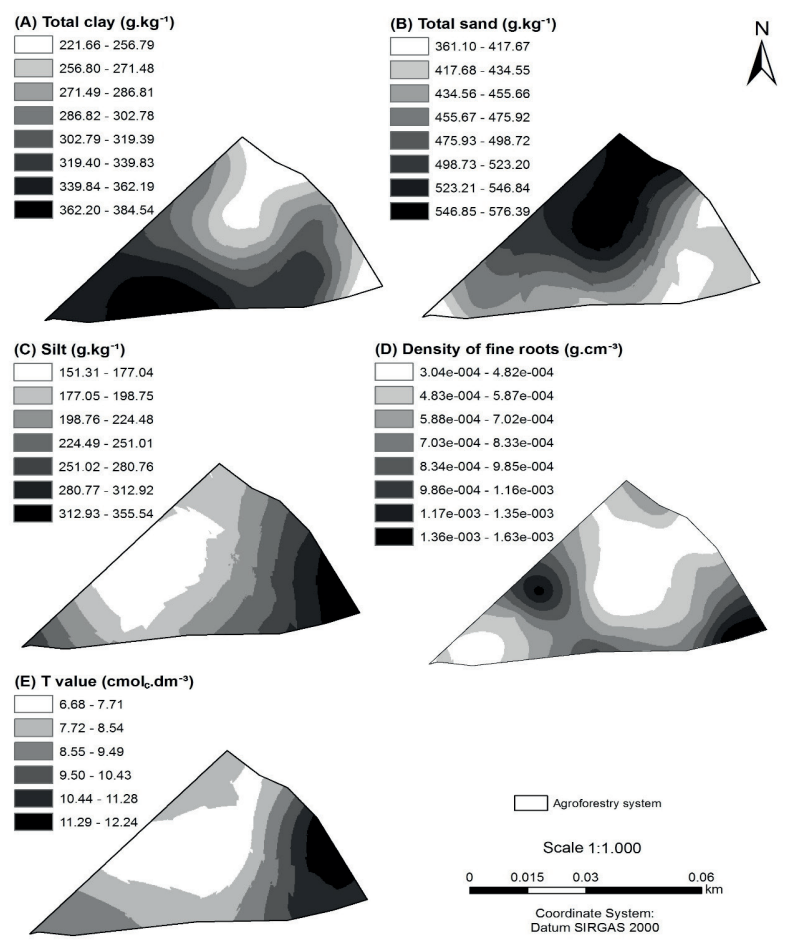

FIGURE 3 Spatial distribution maps of total clay (A), total sand (B), silt (C), density of fine roots (D), and $T$ value (E) in the agroforestry system of the Integrated Agroecological Production System. quantities in weathered tropical soils, especially in more clayey soils.

High concentrations of phosphorus were found in the agroforestry system. The laboratory method for extracting this nutrient may have resulted in an overestimation, given that the area studied was fertilized with natural phosphate and the extractant used was Mehlich I, which is the standard method of extraction by Embrapa in the State of Rio de Janeiro.

The clay fraction (Figure $3 A$ ) showed higher concentrations in areas with medium altitude, while higher sand concentrations (Figure 3B) were found in the highest altitudes, and higher silt concentrations (Figure $3 C$ ) in locations with the lowest altitudes. This may be due to the soil texture distribution being correlated with the topography and declivity of the terrain (LEÃO et al., 20I I). These results corroborate the study performed by Castione et al. (20I5), who found higher concentrations of sand in the upper third, higher concentrations of clay in the lower third, and higher concentrations of silt in the middle and lower third.

In the regions where the highest concentrations of silt were observed, the lowest values of sand were found. Bottega et al. (2013) found similar results in an agricultural production area under a no-tillage system, in which the geospatialization of the silt showed an inverse distribution to that of the concentrations of coarse and fine sand.

The highest values for density of fine roots (Figure 3D) showed a heterogeneous distribution in the agroforestry system, both in higher and lower altitudes. This result may have been influenced by the types of plant species in the AFS, since in these areas there are species belonging to the Arecaceae family, which have a fasciculated and superficial root system.

Christina et al. (20II), in a study performed in Itatinga, São Paulo, confirmed that root development can be influenced by the type of species planted, or by the genetic material and its relationship with the edaphoclimatic conditions.

The results of this work showed the efficiency and viability of applying geostatistics to spatial distribution of soil chemical and physical attributes in the agroforestry system studied, which can be also used in other systems.

\section{CONCLUSIONS}

The geostatistic analysis allowed spatialize the soil chemical and physical attributes, except the variables $\mathrm{T}$ Value and $\mathrm{Mg}^{2+}$, in the agroforestry system of the Agroecological Farm. 
Geostatistics enables the developing of maps, assisting in decision-makings and promotes a specific and rational soil management through the precise placement of soil conditioners and organic fertilizers, providing the input of nutrients to resume the management of the area.

\section{REFERENCES}

ARTUR, A. G.; OLIVEIRA, D. P.; COSTA, M. C. G.; ROMERO, R. E.; SILVA, M. V. C.; FERREIRA, T. O. Variabilidade espacial dos atributos químicos do solo, associada ao microrrelevo. Revista Brasileira de Engenharia Agrícola e Ambiental, v. 18, n. 2, p. |4I-|49, 2014.

BEZERRA, A. L. L.; LIMA, I. M. A.; NASCIMENTO, B. L. M.; AQUINO, B. F. Influência da calagem na adsorção de fósforo em diferentes solos do estado do Ceará. Agropecuária Científica no Semiárido, v. 9, n. 4, p. 0I-05, 2013.

BOTTEGA, E. L.; QUEIROZ, D. M.; PINTO, F. A. C.; SOUZA, C. M. A. Variabilidade espacial de atributos do solo em sistema de semeadura direta com rotação de culturas no cerrado brasileiro. Revista Ciência Agronômica, v. 44, n. I, p. I-9, 2013.

BRIEDIS, C.; SÁ, J. C. M.; CAIRES, E. F; NAVARRO, J. F; INAGAKI, T. M.; FERREIRA, A. O. Carbono do solo e atributos de fertilidade em resposta à calagem superficial em plantio direto. Pesquisa agropecuária brasileira, v. 47, n. 7, p.1007-1014, 2012.

CAJAZEIRA, J. P.; ASSIS JÚNIOR, R. N. Variabilidade espacial das frações primárias e agregados de um Argissolo no Estado do Ceará. Revista Ciência Agronômica, v. 42, n. 2, p. 258-267, 201 I.

CAMBARDELLA, C. A.; MOORMAN, T. B.; NOVAK, J. M.; PARKIN, T. B.; KARLEN, D. L.; TURCO, R. F.; KONOPKA, A. E. Field scale variability of soil properties in central lowa soil. Soil Science Society of America Journal, v. 58, n. 5, p. I50I-I5II, 1994.

CARVALHO, D. F; SILVA, D. G.; SOUZA, A. P.; GOMES, D. P.; ROCHA, H. S. Coeficientes da equação de AngströmPrescott e sua influência na evapotranspiração de referência em Seropédica, RJ. Revista Brasileira de Engenharia Agrícola, v. 15, n. 8, p. 108-116, 2011.

CASTIONE, G. A. F.; SOUZA, Z. M.; SILVA, R. B.; CAMPOS, M. C. C.; CUNHA, J. M. Variabilidade espacial da textura do solo em área irrigada por pivô central em diferentes posições na paisagem. Revista Agroambiente On-line, v. 9, n. 3, p. 219-226, 2015.

CHERUBIN, M. R.; SANTI, A. L.; BASSO, C. J.; EITELWEIN, M. T.; VIAN, A. L. Caracterização e estratégias de manejo da variabilidade espacial dos atributos químicos do solo utilizando a análise dos componentes principais. Enciclopédia Biosfera, Centro Científico Conhecer, v. 7, n. I3, p. 196-210, 201 I.
CHRISTINA, M.; LACLAU, J. P.; GONÇALVES, J. L. M.; JOURDAN C.; NOUVELLON, Y.; BOUILLET, J. P. Almost symmetrical vertical growth rates above and below ground in one of the world's most productive forests. Ecosphere, v. 2, n. 3, p. I-10, 2011 .

CORRÊA, R. M.; NASCIMENTO, C. W. A.; ROCHA, A. T. Adsorção de fósforo em dez solos do Estado de Pernambuco e suas relações com parâmetros físicos e químicos. Acta Scientiarum Agronomy, v. 33, n. I, p. I53-159, 20II.

DALCHIAVON, F. C.; CARVALHO, M. P.; ANDREOTTI, M.; MONTANARI, R. Variabilidade espacial de atributos da fertilidade de um Latossolo Vermelho Distroférrico sob Sistema de Plantio Direto. Revista Ciência Agronômica, v. 43 , n. 3, p. $453-46$ I, 2012.

DONATO, L.; LIMA, M. G. Distribuição geográfica do sistema agroflorestal na região do Vale do Ribeira. Geografia, v. 22, n. 3, p. 47-64, 2013 .

EBELING, A. G.; ANDOS, L. H. C.; PEREZ, D. V.; PEREIRA, M. G.; GOMES, F. W. F. Atributos químicos, carbono orgânico e substâncias húmicas em organossolos háplicos de várias regiões do Brasil. Revista Brasileira de Ciência do Solo, v. 35, n. 2, p. 325-336, 201 I.

EMPRESA BRASILEIRA DE PESQUISA AGROPECUÁRIA. Manual de métodos de análise de solo. Centro Nacional de Pesquisa de Solos, 1997. 212p.

GOIS, G.; DELGADO, R. C.; OLIVEIRA-JÚNIOR, J. F. Modelos teóricos transitivos aplicados na interpolação espacial do índice de precipitação padronizada (SPI) para episódios de El Niño forte no estado do Tocantins. Irriga, v. 20, n. 2, p. $37 \mid-387,2015$.

LEÃO, M. G. A.; MARQUES JUNIOR, J.; SOUZA, Z. M.; SIQUEIRA, D.; PEREIRA, G. T. Terrain forms and spatial variability of soil properties in an area cultivated with citrus. Engenharia Agrícola, v. 31, n. 4, p. 644-65I, 201 I.

LIMA, S. S.; LEITE, L. F. C.; OLIVEIRA, F. C.; COSTA, D. B. Atributos químicos e estoques de carbono e nitrogênio em argissolo vermelho-amarelo sob sistemas agroflorestais e agricultura de corte e queima no norte do Piauí. Revista Árvore, v. 35, n. I, p. 5I-60, $201 \mathrm{I}$.

MARTINS, J. A.; FIORIO, P. R.; DEMATTÊ, J. A. M.; MIRANDA, J. H.; LELIS NETO, J. A. Sensoriamento remoto na determinação de atributos de um Nitossolo sob aplicação de vinhaça. Revista Brasileira de Ciência do Solo, v. 38, n. 3, p. 959-97।, 2014.

MATIAS, S. S. R.; NÓBREGA, J. C. A.; NÓBREGA, R. S. A.; ANDRADE, F. R.; BAPTISTEL, A. C. Variabilidade espacial de atributos químicos em Latossolo cultivado de modo convencional com soja no cerrado piauiense. Revista Agroambiente On-line, v. 9, n. I, p. I7-26, 2015. 
MÉIER, M.; TEIXEIRA, H. M.; FERREIRA, M. G.; FERRARI, E. A.; LOPES, S. I.; LOPES, R.; CARDOSO, I. M. Sistemas agroflorestais em área de preservação permanente. Revista Agriculturas: experiências em agroecologia, v. 8, n. 2, p. I2-I7, 2011 .

NOVAIS, R. F; SMYTH, T. J.; NUNES, F. N. Fósforo. In: NOVAIS, R. F. et al. Fertilidade do solo. Sociedade Brasileira de Ciência do Solo, 2007. p. 472-550.

PELISSARI, A. L.; CALDEIRA, S. F.; SANTOS, V. S. Variabilidade espacial dos atributos químicos do solo em povoamento de Tectona grandis. Cerne, v. 20, n. 3, p. 377-384, 2014.

SANTOS, H. G.; JACOMINE, P. K. T.; ANJOS, L. H. C.; OLIVEIRA, V. A.; LUMBRERAS, J. F.; COELHO, M. R.; ALMEIDA, J. A.; CUNHA, T. J. F.; OLIVEIRA, J. B. Sistema Brasileiro de Classificação de Solos. Embrapa, 2013. 353p.

SOUSA, A. R.; ALBUQUERQUE, S. F.; LOPES, G. M. B.; SILVA, A. B.; FILHO, J. N. Caracterização e interpretação de um Planossolo Háplico Eutrófico do Agreste Pernambucano, Brasil. Anais da Academia Pernambucana de Ciência Agronômica, v.10, n. I, p. 27I-279, 2013.

SOUSA, D. M. G.; MIRANDA, L. N.; OLIVEIRA, S. A. Acidez do solo e sua correção. In: NOVAIS, R. F. et al. Fertilidade do solo. Sociedade Brasileira de Ciência do Solo, 2007. p. 206-274.
TOKURA, A. M.; FURTINI NETO, A. E.; CARNEIRO, L. F; CURI, N.; SANTOS, J. Z. L.; ALOVISI, A. A. Dinâmica das formas de fósforo em solos de textura e mineralogia contrastantes cultivados com arroz. Acta Scientiarum Agronomy, v. 33, n.I, p. I7I-I79, 201 I.

VIEIRA, S. Introdução à Bioestatística. Elsevier, 20 I I. 345p.

VIEIRA, S. R.; DECHEN, S. C. F; SIQUEIRA, G. M.; DUFRANC, G. Variabilidade espacial de atributos físicos e químicos relacionados com o estado de agregação de dois Latossolos cultivados no sistema de semeadura direta. Bragantia, v. 70 , n. I, p. 185-195, 2011 .

ZONTA, J. H.; BRANDÃO, Z. N.; MEDEIROS, J. C.; SANA, R. S.; SOFIATTI, V. Variabilidade espacial da fertilidade do solo em área cultivada com algodoeiro no Cerrado do Brasil. Revista Brasileira de Engenharia Agrícola e Ambiental, v. 18, n. 6, p. 595-602, 2014.

ZUCOLOTO, M.; LIMA, J. S. S.; COELHO, R. I. Correlação e variabilidade espacial de atributos químicos do solo e produção de bananeira 'prata-anã'. Revista Brasileira de Fruticultura, v. especial, p. 479-484, 201 I. 